\title{
Opinions of Community Pharmacists About Collaboration with General Practitioners: A Descriptive Pilot Study After New Legislation in Turkey
}

\author{
Serbest Eczacıların Aile Hekimleri ile Çalışmaları Konusundaki Düşünceleri: \\ Türkiye'deki Yeni Yasal Düzenleme Sonrası Tanımlayıc Bir Pilot Çalışma
}

\author{
(D) Aygin BAYRAKTAR EKINCIOĞLU*, (D) Kutay DEMIRKAN \\ Hacettepe University, Faculty of Pharmacy, Department of Clinical Pharmacy, Ankara, Turkey
}

\begin{abstract}
Objectives: Committed legal regulations in primary healthcare services have resulted in certain issues and requirements about community pharmacy practices in Turkey. A professional collaboration between general practitioners and pharmacists is essential for the continuity of care in primary care settings. Therefore, the aim of this was study to explore community pharmacists' opinions on collaborative care along with new primary care regulations.

Materials and Methods: A web-based questionnaire was implemented during a period of five months to a voluntary sample of community pharmacists. The questionnaire consisted of multiple-choice questions that allowed participants to select more than one answer wherever appropriate.

Results: One hundred ninety-seven community pharmacists responded to the questionnaire; $66 \%$ were younger than 39 years and had less than 15 years' experience in the profession. In general, the pharmacists are willing to be involved in maintaining continuity of care, especially in patient counselling. However, $10.7 \%$ of participants indicated that the main reasons for not being actively involved in patient care were 'mainly dealing with explaining prescription co-payment procedures' and 'having unfavorable attitudes of other healthcare professionals'. They believed that their contributions were restricted by laws and regulations (14.2\%) as well as declined perceived reputation (53.8\%) of the profession among the public. Conclusion: Revealing misperceptions among patients and healthcare professionals, overcoming limitations of current practice and an understanding of each profession's responsibilities may lead to formation of a new and more effective model of care.
\end{abstract}

Keywords: Patient-centered practice, interprofessional, collaboration, pharmacist, general practitioner

öz

Amaç: Birinci basamak sağlık hizmetlerinde yapılan yasal düzenlemeler, serbest eczacılık hizmetlerinde bazı hususların ve ihtiyaçların ortaya çıkmasına neden olmuștur. Birinci basamak sağlık hizmetlerinde eczacılar ve aile hekimleri arasındaki profesyonel ișbirliği, sağlık bakım hizmetinin devamlıığının sağlanması için gereklidir. Bu nedenle bu çalışma, serbest eczacıların birinci basamak sağlık hizmetlerindeki yeni düzenlemeler ile, işbirliği şeklindeki bakım hizmetleri hakkındaki görüşlerini ortaya koymayı amaçlamaktadır.

Gereç ve Yöntemler: İnternet sayfası tabanlı anket çalışması, 5 ay süre ile, gönüllü olarak katılım sağlayan bir serbest eczacı örneklemine uygulanmıștır. Anket, çoktan seçmeli sorulardan oluşmaktadır ve gerektiğinde katılımcıların birden fazla seçenek seçmesine olanak sağlamaktadır.

Bulgular: Çalıșmada, 197 serbest eczacı soruları cevaplamıştır; katılımcıların \%66'sı >39 yaș ve 15 yıldan daha az tecrübesi olan eczacılardır. Genel olarak, eczacılar bakımın devamlıığını sağlamak konusunda, özellikle hasta danışmanlığında, katıımcı olmaya istekli olduklarını belirtmiştir. Ancak, katılımcıların \%10.7'si, aktif olarak hasta bakımına katılamamanın temel nedeninin; 'reçete geri-ödeme prosedürleri ile uğraşmak' ve 'diğer sağlık çalışanları tarafından teșvik edici olmayan tavırlar' olduğunu belirtmiştir. Katıımcılar, bu katkılarının var olan yasal düzenlemeler (\%14.2) ve toplumda azalan saygınlık (\%53.8) nedeniyle kısıtlandığına inanmaktadır.

Sonuç: Hastalar ve sağlık çalışanları arasında var olan yanlış algıların açığa çıkarılması, var olan hizmetteki sınırlamaları ortadan kaldıracak ve her mesleğin sorumluluklarının anlaşılması, yeni ve daha etkin bir bakım modelinin oluşturulmasına yardımcı olacaktır.

Anahtar kelimeler: Hasta-odaklı uygulama, mesleklerarası, işbirliği, eczacı, aile hekimi

*Correspondence: E-mail: aygin@hacettepe.edu.tr, ORCID-ID: orcid.org/0000-0002-3481-0074

Received: 14.02.2017, Accepted: 17.08.2017

๑Turk J Pharm Sci, Published by Galenos Publishing House. 


\section{INTRODUCTION}

An improvement in the healthcare system depends on stakeholders who perform the required responsibilities and expanded professional competencies and skills. In terms of chronic disease management, both primary and secondary care health professionals should play active roles in patient care.

In Turkey, the National Health Service in primary care has been revised and general practitioners' (GPs) roles have been expanded since 2010. The new legislation on the primary health care process was introduced in 2013 and revised in 2015. By January 2013, electronic prescribing also began to be implemented in Turkey. Previously, GPs were responsible for monitoring chronic diseases as well as providing preventive health services along with the nurses in primary care settings. Before the new legislation, GPs practicing in primary care settings were only allocated in a small and a limited number of community clinics in a city where they only have close contact with nurses for the patient care process. Patients were free to attend any community clinics for their monitoring and prescriptions according to their preferences. After the legislation, the patients are obliged to attend a certain healthcare center and monitored by an assigned GP according to their home addresses, and were not allowed to change their doctor within the first 3 months. Patients are guided to visit GPs first before attending secondary or tertiary care settings where health expenses could not be covered by the national health insurance.

Groups of GPs (e.g. minimum 2 doctors) are also allocated in certain healthcare centers according to the population size and number of patients to be served. They are entitled to serve a minimum of 3500-4000 patients, work a total of 40 hours per week depending on the total population number in a district. If the assigned number of patients for GPs declines below 1000 patients in a minimum 2 consecutive months, their agreements with the national health service becomes invalid. With the implementation of new legislation, the roles are merged between GPs and nurses, where monitoring of chronic diseases is focused by doctors and preventive health services are undertaken by nurses, which has led to disunity of health services in primary care. There is also a growing interest in clinical pharmacy practice about expanding the role of pharmacists to be actively involved in the patient care process. Unlike most European countries, clinical pharmacy is a new and emerging concept in Turkey and has gained the attention of pharmacists, as well as other healthcare professionals.

According to a report of the Turkish Ministry of Health, patients' primary care visits increased to 2.7 visits per patient/year in 2010 compared with 0.9 visits per patient/year in 2002. A recent study conducted by Çiceklioğlu et al. ${ }^{2}$ indicated that GPs' professional identities have shifted to businesspeople from healers, workloads are increased, and more patients behave as demanding consumers as result of the Turkish Health Transition Program. Given the fact that there are a large number of community pharmacists, a rational use of pharmacy services is inevitable. Therefore, novelties in primary care services create opportunities for both professions in terms of shared responsibilities in the patient care process.

The role and contribution of pharmacists in patient monitoring has been well documented in the literature, mainly in chronic disease management; ${ }^{3-5}$ however, there was a low tendency to report the perceptions, attitudes, and opinions of healthcare providers. Wüstmann et al. ${ }^{6}$ determined the views and attitudes of pharmacists and GPs in Germany towards each other regarding collaboration. They concluded that although the frequency of contact was low, there was a good level of trust between both professions. Moreover, pharmacists and GPs regard that their responsibilities are important in maintaining patient adherence to drug treatment in the long-term, but more frequent co-operation is necessary.

Bryant et al. ${ }^{7}$ explored the GPs' perceptions on the expanding role of the community pharmacist in clinical medication reviews. They showed that GPs regarded pharmacist's skills as valuable, supportive in repeat dispensing schemes, and helpful in patients' medication management; however, they indicated that the value of services provided by a pharmacist should be balanced between improved patient outcomes and resources (time and funding) required.

On the other hand, it has been shown that ${ }^{8}$ more than half of all GPs support the involvement of pharmacists in the activities of providing public health education, contacting GPs on matters related to prescribing and prescription errors, and referring patients who exhibit drug-related problems. However, less than half have doubts regarding pharmacists' role in a smoking cessation program and the provision of drug information to doctors.

According to Van et al. ${ }^{9}$, attitudes towards collaboration are strongly related to communication, mutual respect, willingness to work together, and the recognition of roles, which are influenced by trust and expectation. One of the common barriers indicated by Hughes and McCann ${ }^{10}$ was the professional image of community pharmacists, which also affects public perception and awareness with regards to the care they receive from pharmacists. Furthermore, the integration of pharmacists and remuneration are also considered as barriers. ${ }^{11}$

The factors that affect pharmacist-GP collaboration have also been identified by Rubio-Valera et al., ${ }^{12}$ who showed the associated factors as perception of usefulness, the clinic manager's interest, professional attitude, geography, and legislation. Similar findings were documented by Saramunee et al.,13 indicating that community pharmacies were a good source for advice on medicines and minor ailments but were less supportive in public health services. The main barriers that can interfere with service use were listed as the perceptions of both the general public and other health providers towards pharmacists' competencies, privacy and confidentiality in pharmacies, high dispensing workload, and inadequate financial 
support. Therefore, a clearer understanding of the perceptions of health professionals is crucial for establishing a continuous collaboration in the patient care process.

Bryant et al. ${ }^{14}$ indicated that there were significant barriers preventing community pharmacists from becoming involved in clinical services because of the lack of acceptance of clinical roles in disease management. However, GPs strongly agreed with the pharmacists' role in patient counselling, education, compliance, and reporting adverse events.

Many studies have reported GPs' perspectives and opinions on a collaborative care; however, few studies have searched for pharmacists' opinions. It is important to reveal the level of willingness of participation and professional trust in the competencies of pharmacists in collaboration. Furthermore, no studies have been conducted in Turkey among health professionals in order to identify their opinions and perceptions on a shared care process after the introduction of the new health transition program. Therefore, the aim of this study was to identify community pharmacists' opinions on a shared care process and their willingness to be involved in patient monitoring in order to improve quality in primary health care settings.

\section{MATERIALS AND METHODS}

The survey study was undertaken via a web-based questionnaire (www.teb.org.tr) with the support of the Turkish Pharmacists Association (TEB). The questionnaire was initially designed by the researchers in view of the literature, and sent by e-mail to 20 pharmacists from different cities in order to clarify the meaning and understanding of questions. According to the responses and comments from pharmacists, some questions were reworded and some others were omitted from the study. The revised final questionnaire comprised a total of 27 questions; nine regarding the pharmacist's/pharmacy's demographics, and other questions were related to the pharmacist's opinions on the implementation of the new legislation and collaboration with GPs. The participants were allowed to choose more than one answer wherever appropriate.

No similar studies have been undertaken among the Turkish pharmacists previously; therefore, the researchers had no reference values to calculate a sample size based on any assumptions for this study. Community pharmacists who are willing to participate in the study entered the web system using either their social security institution identification number or a prescription issue entry number, then completed the questionnaire on the web page of the TEB.

Ethics committee approval was not sought for this study and it was undertaken collaboratively with the TEB. The association is an official representative council of pharmacists in Turkey, and the survey was an initiative of the association in order to explore the perspectives of its members about the newlyemerged situation in the healthcare system in order to improve pharmacy services to be re-established in Turkey.

\section{Statistical analysis}

At the end of the data collection period, the responses were collected through a web-based program and the data were analyzed by statisticians using SPSS-11.

\section{RESULTS}

During five-month period, a total of 200 pharmacists responded to the questionnaire; three questionnaires were excluded from the analysis due to a lack of data. Two thirds of the pharmacists who participated in this study were aged younger than 40 years and had less than 15 years' experience in the profession. The majority of pharmacies were located near a GP practice and dispensed 26-50 prescriptions per day. The details of the participants are summarized in Table 1.

Table 1. Characteristics of the participants in the study

n (\%)

\begin{tabular}{ll}
\hline Sex & \\
Male & $118(59.9)$ \\
Female & $79(40.1)$ \\
\hline Age & \\
$\leq 30$ & $53(26.9)$ \\
$31-39$ & $77(39.1)$ \\
$40-49$ & $41(20.8)$ \\
$\geq 50$ & $26(13.2)$ \\
\hline
\end{tabular}

Year of experience in the profession;

$\leq 5$ years

6-15 years

$42(21.3)$

$16-25$ years

$89(45.2)$

$\geq 26$ years

$39(19.8)$

27 (13.7)

Educational level;

University

$168(85.3)$

$\mathrm{MSc} / \mathrm{PhD}$ (postgraduate qualification)

$29(14.7)$

Location of pharmacy;

Main street

48 (24.4)

Near hospital/medical clinic

$35(17.8)$

Near GP practice

$92(46.7)$

City center/in the mall

$22(11.2)$

Number of prescriptions dispensed per day

$1-25$

$26-50$

34 (17.3)

$51-75$

$89(45.2)$

76-100

$49(24.9)$

101-125

$19(9.6)$

126-150

$4(2.0)$

$1(0.5)$

$\geq 151$

$1(0.5)$

Number of patients' visit to the pharmacy per day $1-25$

$26-50$

$51-75$

$19(9.6)$

55 (27.9)

$76-100$

49 (24.9)

$101-125$

$45(22.8)$

126-150

$17(8.6)$

$\geq 151$

$8(4.1)$

$4(2.0)$

GP: General practitioner 


\section{Influence of new legislation on pharmacy practice}

According to the study results, the change in healthcare legislation in Turkey has caused $19.8 \%$ of pharmacists to change the location of their pharmacies in order to be near a GP practice. Pharmacy health services were also affected by this new legislation and its impact on pharmacies was in both extents. More than $45 \%$ of the pharmacists agreed that the number of drug varieties (46.2\%), dispensed drugs that should be prescribed by a specialist (47.2\%), and patients' visits to pharmacies for counselling (48.7\%) had increased, whereas the number of dispensed prescriptions (41.6\%) had decreased.

\section{Professional interactions with GPs}

In this study, most of the pharmacists reported the frequency of their contact with GPs about patients' prescriptions and health status was 1-5 times per week (43\%) or never (19\%). Instead, the majority of GPs had never (52\%) or 1-5 times per week (36\%) contacted pharmacists. The pharmacists who contacted GPs 1-5 times per week mainly dispensed $26-50$ prescriptions per day (50.5\%) and were located near the GP practice (48.2\%), a hospital/health center (22.3\%), on a main street $(22.3 \%)$ or in a city center/near a shopping mall (7.2\%). Interestingly, the pharmacists who never contacted GPs were also located near the GP practice (51.3\%). There was no difference between pharmacists who did and did not contact GPs in terms of sex, age, the number of dispensed prescriptions, and the location of the pharmacy $(p<0.05)$. Only $16.2 \%$ of the pharmacists stated having a positive communication with GPs (Table 2).

With regards to the common issue of communication between a pharmacist and GP, GPs mainly contacted pharmacists regarding the reimbursement status of a drug from National Social Security (55.8\%), whether a patient had sufficient medication until the next visit $(13.7 \%)$ or eligibility of a drug in the market (11.7\%). Similarly, pharmacists contacted GPs if any inconsistency was recognized between a prescription and a patient's health report (74\%) or for correcting any errors in the prescriptions (16.2\%). Unfortunately, neither GPs nor pharmacists contacted each other regarding drug use, dose and dosing errors or any potential drug interactions, according to the pharmacists' opinion.

In consideration of the pharmacist-GP relationship, although over half of the pharmacists indicated that their professional relationship with GPs had not changed by this new legislation, the proportion of pharmacists who believed that communication

Table 2. Pharmacists' professional communication with general practitioners

\begin{tabular}{ll} 
Behaviors of the GPs perceived by pharmacist & $\mathrm{n}(\%)$ \\
\hline $\begin{array}{l}\text { Distant relations and asking questions to GPs not } \\
\text { allowed }\end{array}$ & $69(35.0)$ \\
\hline Closed to any kind of communication & $68(34.5)$ \\
\hline Descriptive, informative and constructive & $32(16.2)$ \\
\hline
\end{tabular}

GPs: General practitioners regarding a patient referral to a GP and a GP's referral to a pharmacy for counselling ( $31 \%$ vs. $24.4 \%$ ) and the provision of drug information by a pharmacist to GPs (28.4\%) were increased.

\section{Perceived roles of pharmacists in collaborative care}

The participants considered the role of a pharmacist in drug treatment as counselling/providing drug information (47.2\%), joint decision-maker with doctors (28.4\%), monitoring drug use (17.8\%), a decision-maker (3.6\%), and a pharmacoeconomic supervisor in drug use (3.0\%). The participants who considered pharmacists as a consultant (93 out of 197) and a joint decisionmaker (56 out of 197) were mainly aged 31-39 years (38 out of 93 vs. 19 out of 56) and had 6-15 years of experience (40 out of 93 vs. 25 out of 56). The pharmacists who were aged over 50 years (26 out of 197) considered the pharmacist's role more likely to be counselling/providing drug information (17 out of 26).

Eighty-four percent of pharmacists $(n=165$, of whom $42 \%$ were female and $58 \%$ were male; $38 \%$ were $31-39$ years and $29 \%$ were $<30$ years) believed that the role of pharmacists in counselling should focus on providing information about drugs and patients' diseases. Nevertheless, the provision of information by pharmacists about drug interactions, the selection of an appropriate drug, dose forms and dosage were not acknowledged by the participants.

With respect to the influence of new legislation on the patientpharmacist relationship, more than half the pharmacists reported that communication with patients had increased when it came to providing information about drugs and reimbursement status. Although $50.8 \%$ of the participants indicated that the perception of pharmacists' roles in preventive public health services (smoking cessation, vaccines, healthy nutrition) were not changed, an increased perception was also reported by $37.6 \%$ of the responders.

\section{Preferred roles of pharmacists in collaborative care}

The participants (\%) believed that if they had access to detailed patient medical records through the National Social Security System they could;

- Counsel about public and preventive health (family planning, vaccines, obesity and smoking cessation) (65.5\%),

- Provide drug information to doctors about appropriate drug and dose forms as well as drug interactions (60.9\%),

- Advice drugs for a minor illness (such as cold and flu, acne, fungal infections and scabies) (79.2\%) to patients,

- Maintain patient care in collaboration with doctors according to the treatment guidelines (58.9\%),

- Review patient's drugs and laboratory results and refer to a doctor early if required (65\%),

- Work on pharmacovigilance (75.6\%),

- Help to increase patient adherence (70.1\%),

- Dispense repeat prescriptions without the need for a patient to be seen by a doctor (61.9\%). 
Table 3. The pharmacists' reasons for not being able to be involved in a patient's drug treatment

\begin{tabular}{ll}
\hline Reasons & $\mathrm{n}(\%)$ \\
\hline Too much time to explain the prescription co-payment & $21(10.7)$ \\
\hline Lack of patients' time & $4(2.0)$ \\
\hline $\begin{array}{l}\text { Slow data entrance system of the National Social } \\
\text { Security System }\end{array}$ & $7(3.6)$ \\
\hline No reimbursement for such specific service & $2(1.0)$ \\
\hline $\begin{array}{l}\text { Unfavorable attitudes of other health care profession- } \\
\text { als }\end{array}$ & $21(10.7)$ \\
\hline $\begin{array}{l}\text { Unfavorable attitudes of patients } \\
\text { Legal limitations }\end{array}$ & $8(4.1)$ \\
\hline $\begin{array}{l}\text { Perceived status of the pharmacy profession among } \\
\text { the public }\end{array}$ & $106(53.8)$ \\
\hline
\end{tabular}

The participants were asked to give their opinions on their active roles in a patient's drug treatment, including over-the-counter drugs. Approximately $76 \%$ of the participants (61 females, 88 males) believed they had active roles in drug treatment, of which $46 \%$ generally worked near a GP's practice and received and/or dispensed 26-50 prescriptions per day. However, a majority of the pharmacists (54\%) stated not being involved in collaborative drug treatment processes in daily practice (Table 3 ).

Moreover, the participants highlighted professional needs in order to provide counselling services to patients and healthcare professionals. Forty-two percent of participants indicated that they should be acquainted with the legal regulations on drug reimbursement, whereas $37 \%$ believed that they should have a continuous/uninterrupted transfer of electronic patient records from GPs. Only 3\% reported that they needed to follow professional educational programs in order to provide such services.

\section{Reimbursement of pharmacy services}

In regards to reimbursement of such services provided by pharmacies, the participants indicated that reimbursement could be gradually incremented on the basis of the number of prescriptions and/or drug boxes (34.5\%), the number of health services provided and documented by a pharmacist (20.3\%), or a fixed amount according to the number of working hours per month (18.3\%).

\section{DISCUSSION}

Along with the initiation of new legislation, there would be an opportunity for close collaboration between pharmacists and GPs in the patient monitoring process and other primary healthcare activities.

Previous studies have already focused on potential barriers for communication among healthcare professionals and collaborative healthcare services in different practice settings, such as medication review, medicine management, patient/ health education, ${ }^{15}$ and prescribing/prescription errors and early referrals to GPs. $8,11,16$
A study from Malaysia has shown similar findings, where a majority of community pharmacists were still focusing on counselling for nutritional supplement, cough and cold, and diabetes, and providing screening tests for blood pressure and blood sugar levels. Generally, GPs were supportive towards the involvement of pharmacists in extended pharmacy services but they were uncertain about the knowledge and skills. Most of the GPs indicated that they would like to collaborate with community pharmacists on improving patient therapeutic outcomes ( 55\%) and welcome patient referral from community pharmacies for further medical evaluation ( 70\%). However identified barriers was listed as lack of time, shortage of man power, lack of collaboration between healthcare professionals, legal and regulatory constraints, and lack of self-efficacy. ${ }^{17}$

According to the results of this study, communication between pharmacists and GPs was infrequent and described as distant and did not allow for further discussion; furthermore, collaboration in decision-making or shared information during patient care did not seem to be feasible in routine practice. Information shared by health professionals was mainly on technical or bureaucratic issues rather than individual professional knowledge. Therefore, the perception of each profession and their expectations were restricted; it would take time to establish the inter-professional trust between GPs and pharmacists in taking responsibilities of patient care.

In the present study, it was also reported that community pharmacists had conflicting opinions on working in collaboration with GPs in primary care. Although there has been apparent enthusiasm about being involved in patient care, pharmacists were not in favor of providing such services with no reimbursement. Moreover, $10.7 \%$ of participants indicated that they were exhausted about explaining prescription copayment procedures and unfavorable attitudes of other healthcare professionals, which were the main reasons for not being actively involved in drug treatment.

Community pharmacists were enthusiastic about providing drug information; however, they were reluctant to take an active role in patient monitoring because of legal limitations, reimbursement problems, and the perceived reputation of community pharmacists among the public.

With the implementation of new legislation, $19.8 \%$ of the pharmacists had to change the location of their pharmacies. Through a dissemination of increased numbers of GP practices around different locations, pharmacies also had to change their location in order to maintain their income and sustain the quality of pharmacy services. It is necessary to indicate that all community pharmacists are self-employed in Turkey. Therefore, macro- or micro- economic changes may affect pharmacies' income due to relatively high leases and low fees for professional counselling. 


\section{Study limitations}

The main limitation of the study is the number of participants. The questionnaires were not delivered to pharmacists personally, instead they was uploaded on the website on the 'news' section of the TEB web page. Pharmacists generally visit the website in order to reach updated information about legal procedures in pharmacy practice or reimbursement of particular drugs, not to complete questionnaires. Therefore, not many pharmacists were likely to participate in the study and the web-based questionnaire was not the most appropriate method for this group of pharmacists.

The study was undertaken soon after the new legislation was implemented; therefore, the participants might not have clear/ robust views about its impact. It would be better to surrogate the questions in the future when the implication of the legislation will be more sustained. Although the results of this study might not reflect the opinions of all pharmacists, it can still be considered as a critical overview of pharmacy practice in primary care.

It would also be interesting and invaluable to reflect and compare a sample of GPs' views and expectations along with the participated pharmacists at the same time, which would create a perspective for future studies. However, it could not be manageable for this study; therefore, it can be considered as another limitation.

It is believed that the study results managed to highlight some of the main problems and eventual solutions for a shared care process in primary care. By the results of this study, another pilot project was initiated by the TEB in order to identify pharmacist's role in monitoring patients with hypertension in collaboration with GPs. The professional bodies found an opportunity to lead the legal authorities and guide the pharmacists in terms of professional improvements in the country.

\section{CONCLUSION}

Such practice implications are unique for pharmacists where the concept of clinical pharmacy practice is not well-established in countries such as Turkey. Therefore, determination of needs and expectations, and identification of barriers and challenges in local/national health care settings will expand the ideas of practitioners in improving collaborative care.

Local implementation of European healthcare models for the continuity of care in primary care settings may enlighten different countries in order to enhance health services; however, variations in regulations of health systems may lead to occurrence of reluctance in contribution. An integration of clinical governance within a primary care process by active involvement of pharmacists may yield shared-decision making in drug therapy, reduce workloads of GPs, and also enhance patient satisfaction.

Community pharmacists are willing to participate in the patient care process and they are best-positioned to provide drug information and monitor patients' health outcomes in pharmacies. A delegation of responsibilities by laws and regulations would give confidence to pharmacists and maintain collaborative care for patients. A communication pathway between GPs and pharmacists should be re-arranged by a healthcare model that is designed according to technical issues on prescriptions, which meets the mutual professional expectations of each profession.

\section{ACKNOWLEDGEMENTS}

We would like to thank the Turkish Pharmacists Association for their kind support and Mr. Ömer Kutlu and Ms. Özge Bal for their contribution during data analysis and Mr. İlker Mintaş (M.D, General Practitioner) for his invaluable advices.

Conflict of Interest: No conflict of interest was declared by the authors.

\section{REFERENCES}

1. The Republic of Turkey The Ministry of Health. The Ministry of Health of Turkey Health Statistics Year Book 2010. Ankara: The Ministry of Health Refik Saydam Hygiene Center Presidency School of Public Health.; 2011. Report No.: Contract No: 832.

2. Çiceklioğlu M, Öcek ZA, Turk M, Taner Ş. The influence of a marketoriented primary care reform on family physicians' working conditions: A qualitative study in Turkey. Eur J Gen Pract. 2015;21:97-102.

3. Chua SS, Kok LC, Yusof FA, Tang GH, Lee SW, Efendie B, Paraidathathu T. Pharmaceutical care issues identified by pharmacists in patients with diabetes, hypertension or hyperlipidaemia in primary care settings. Bmc Health Serv Res. 2012;12:388.

4. Tan EC, Stewart K, Elliott RA, George J. Pharmacist services provided in general practice clinics: A systematic review and meta-analysis. Res Soc Adm Pharm. 2014;10:608-622.

5. Geurts MM, Talsma J, Brouwers JR, de Gier JJ. Medication review and reconciliation with cooperation between pharmacist and general practitioner and the benefit for the patient: a systematic review. Brit $J$ Clin Pharmacol. 2012;74:16-33.

6. Wüstmann AF, Haase-Strey C, Kubiak T, Ritter CA. Cooperation between community pharmacists and general practitioners in eastern Germany: attitudes and needs. Int J Clin Pharm-Net. 2013;35:584-592.

7. Bryant L, Coster G, McCormick R. General practitioner perceptions of clinical medication reviews undertaken by community pharmacists. J Primary Health Care. 2010;2:225-233.

8. Azmi S, Nazri N, Azmi AH. Extending roles of community pharmacists: views from general medical practitioners. Med J Malaysia. 2012;67:577-581.

9. Van C, Costa D, Abbott P, Mitchell B, Krass I. Community pharmacist attitudes towards collaboration with general practitioners: development and validation of a measure and a model. Bmc Health Serv Res. 2012;12:320.

10. Hughes CM, McCann S. Perceived interprofessional barriers between community pharmacists and general practitioners: a qualitative assessment. Brit J Gen Pract. 2003;53:600-606.

11. Freeman C, Cottrell WN, Kyle G, Williams I, Nissen L. Integrating a pharmacist into the general practice environment: opinions of pharmacist's, general practitioner's, health care consumer's, and practice manager's. Bmc Health Serv Res. 2012;12:229. 
12. Rubio-Valera M, Jove AM, Hughes CM, Guillen-Sola M, Rovira M, Fernandez A. Factors affecting collaboration between general practitioners and community pharmacists: a qualitative study. Bmc Health Serv Res. 2012;12:188.

13. Saramunee K, Krska J, Mackridge A, Richards J, Suttajit S, PhillipsHoward P. How to enhance public health service utilization in community pharmacy?: General public and health providers' perspectives. Res Social Adm Pharm. 2014;10:272-284.

14. Bryant LJ, Coster G, Gamble GD, McCormick RN. General practitioners' and pharmacists' perceptions of the role of community pharmacists in delivering clinical services. Res Social Admin Pharm. 2009;54:347-362.

15. Tan EC, Stewart K, Elliott RA, George J. Pharmacist consultations in general practice clinics: The Pharmacists in Practice Study (PIPS). Res Social Adm Pharm. 2014;10:623-632.

16. Bidwell S, Thompson L. GPs, community pharmacists and shifting professional boundaries. N Z Med J. 2015;128:19-26.

17. Ooi GS, Hassali MAA, Shafie AA, Kong DC, Mak V, Chua GN. Assessment of Community Pharmacy Services in Malaysia: Perspectives from Community Pharmacists, General Practitioners, Consumers and Health Policy Stakeholders. Value Health. 2016;19:807-918. 